2019 ECONOMY Vol. 14. No. 3

\title{
IDENTIFYING AND MANAGING RISK IN ORGANIZING CULTURAL EVENTS (IN THE CASE STUDY OF THE ROMANIAN MUSIC FESTIVALS)
}

\author{
Razvan Liviu Nistor \\ ORCID ID: 0000-0002-3897-3946, e-mail: rasvan.nistor@econ.ubbcluj \\ Amalia Cristina Nedelcut \\ ORCID ID: 0000-0003-3854-863X, e-mail: amalia.nedelcut@econ.ubbcluj
}

Babes-Bolyai University, Faculty of Economics and Business Administration

(Str. Teodor Mihali, Nr. 58-60 400591, Cluj Napoca, Romania)

Cultural management is mainly focused on the establishment of efficient organizational solutions or models that contribute to the growth of added values in market economy and to the increase of investment and competitiveness attractiveness of an area. Correspondingly, cultural events can stimulate the development of local communities, improve their image and attract additional investments. Due to this fact and because of a widely applied subject of the cultural management the interest to the publications in the branch has recently increased. The purpose of the study is to reveal main risks in the organization of cultural events to improve the quality of their organization process. The novelty of the investigation concerns the justification of the criteria for organizational risks of cultural events and the definition of factors of management effect that will contribute to high quality of cultural event organization. Five parameters have been determined as the criteria for organizational risk in the research. They are types of risk; factors that may influence the organization of a cultural event; the relationship between the types of risk and the quality of the organization of cultural events; measures, that can be taken to neutralize potential risks; the effectiveness of management measures, that influence the identified risks. The research is based on the expert survey of organizers, administrative staff, volunteers and artists who participated in two festivals. The festivals are similar in aims and features of holding as they both promote Romanian music - Cluj Modern and Trio Transilvan. The research includes economic and statistical methods applied to the analysis of expert survey results. During the expert survey we have revealed that the organizers of the Trio Transilvan festival are somewhat detached about the various negative influences that could affect the development of the event. Insufficient human resources involved in the event organization or their low quality are critical for the festival. The situation when the scope of the event is higher than the expected number of participants is less critical. As for the Cluj Modern festival is concerned, it should be noted that the average values for the five analyzed criteria of organizational risk correspond to the average probability of its implementation. Herewith, risks associated with human resources are high, whereas risks associated with poor quality of event organization is significantly low. In general, the factors of negative impact on the organization of cultural events, performing social and educational missions, are low level of professionalism of the organizers of cultural event, insufficient investment in improving the quality of their human capital, insufficient attention to marketing and financial issues, the lack of a strategy for promoting the event, the invitation of artists, who are partly involved in the show industry. Taking into account the above mentioned information, the studies devoted to the development of theoretical and methodological foundations and practical guides for the integration of organizational risk factors into cultural event management that will consider the features of the national culture in order to improve the quality of their organization, decrease the impact of financial, marketing, information and other restrictions will be promising.

Keywords: cultural management, cultural event, music festival, risk, risk management, spatial development, local communities, expert survey, economic and statistical analysis. 


\title{
ИДЕНТИФИКАЦИЯ И УПРАВЛЕНИЕ РИСКАМИ В ОРГАНИЗАЦИИ КУЛЬТУРНЫХ МЕРОПРИЯТИЙ (НА ПРИМЕРЕ МУЗЫКАЛЬНЫХ ФЕСТИВАЛЕЙ В РУМЫНИИ)
}

\author{
Разван Ливиу Нистор \\ ORCID ID: 0000-0002-3897-3946, e-mail: razvan.nistor@econ.ubbcluj.ro \\ Амалия Кристина Неделькус \\ ORCID ID: 0000-0003-3854-863X, e-mail: amalia.nedelcut@econ.ubbcluj
}

Университет Бабеш-Бойяи (Румыния, 400591, г. Клуж-Напока, ул. Теодора Михали, 58-60)

Менеджмент в сфере культуры в основном сосредоточен на поиске и обосновании эффективных управленческих решений или моделей, которые способствуют приращению добавленной стоимости в рыночной экономике и обеспечивают рост инвестиционной привлекательности и конкурентоспособности территорий. Соответственно проведение культурных мероприятий может стать экономическим импульсом развития местных сообществ, улучшить их имидж и привлечь дополнительные инвестиции. В связи с этим в последние годы существенно возрос интерес к публикациям в области культурного менеджмента, предмет исследования которого имеет широкое применение. Цель исследования выявление основных рисков в организации культурных мероприятий для улучшения качества их проведения. Новизна заключается в обосновании критериев организационного риска культурного мероприятия и определении факторов управленческого воздействия, обеспечивающих высокое качество организации культурного мероприятия. Критериями организационного риска в исследовании выступили пять параметров: типы риска; факторы, которые могут повлиять на организацию культурного мероприятия; взаимосвязь типов риска и качества организации культурного мероприятия; действия, которые могут быть предприняты для нейтрализации потенциальных рисков; эффективность управленческих мер воздействия на идентифицированные риски. Исследование проведено на базе экспертного опроса организаторов, административного персонала, волонтеров и артистов двух схожих по целям и особенностям проведения фестивалей, продвигающих румынскую музыку, - Cluj Modern и Trio Transilvan. Методика исследования включает применение экономико-статистических методов анализа результатов экспертного опроса. В ходе экспертного опроса установлено, что организаторы фестиваля Trio Transilvan не уделяют должного внимания различным негативным последствиям, которые могут повлиять на организацию и проведение мероприятия. Критичным для данного фестиваля является риск нехватки и низкого качества человеческих ресурсов, вовлеченных в организацию мероприятия, наименее критичным - ситуация, когда масштаб мероприятия шире, чем ожидаемое количество участников. Что касается фестиваля Cluj Modern, то следует отметить, что средние значения для пяти проанализированных критериев организационного риска соответствуют средней вероятности его реализации. При этом наивысшие оценки риска также имеет фактор человеческих ресурсов, наименьшие - риск, связанный с низким качеством проведения мероприятия. В целом факторами негативного воздействия на организацию культурных мероприятий, выполняющих социальную и образовательную миссии, являются: низкий уровень профессионализма организаторов культурного мероприятия, недостаточные инвестиции в повышение качества их человеческого капитала, недостаточное внимание к маркетинговым и финансовым вопросам, отсутствие стратегии продвижения мероприятия, приглашение артистов, ограниченно вовлеченных в шоу-индустрию. С учетом вышесказанного перспективными становятся исследования по разработке теоретико-методологических оснований и практических рекомендаций интеграции факторов организационного риска в модели управления культурными мероприятиями с учетом особенностей национальной культуры в целях повышения качества их проведения, а также для нивелирования воздействия финансовых, маркетинговых, информационных и прочих ограничений.

Ключевые слова: менеджмент в сфере культуры, культурное мероприятие, музыкальный фестиваль, риск, управление рисками, пространственное развитие, местное сообщество, экспертный опрос, экономико-статистический анализ.

\section{Introduction}

$\mathrm{F}$ Testivals characterized performances endowed with a repetitive character and which can be organized both by professionals and non-profit entities from the cultural or artistic field [1]. However, institutions providing cultural performances or activities require the adoption of flexible management actions with the task of adapting to unexpected challenges [2]. Continuous efforts to launch new cultural products 
represent one of the directions studied by the specialists in the domain [3-7]. Festivals can provide an economic boost to the local communities which host their organization, providing opportunities for value-added activities, especially for locals, as well as a fact signalled by researchers: they improve the image of a particular location [8]. This accounts for the support and development of the festivals in relation to local economic development strategies [9; 10] as well as their inclusion into economic policies, contributing, on regional and local level, to the development of the cultural potential. Identifying and assessing risk situations should be attributes specific to an organizational entity, risk management being one of the important components in staging a festival. This involves identifying and assessing risks along with establishing measures to reduce the possibilities of occurrence, or to mitigate the consequences of their materialization, respectively $[11 ; 12]$. Music festivals contain "virtually every risk imaginable" asserted Bethan Moorcraft in Insurance Business UK (February, 2019), emphasizing the need to create risk avoidance strategies, from a complete perspective, from a marketing, operational, and financial standpoint [13].

In order to support the implementation of a coherent risk prevention strategy for two festivals built on a similar theme, the organizing institutions of these two events initiated an investigation that aimed at identifying the strategic risks that could affect the effectiveness of the activities related to their specific objectives. The two festivals share some common traits, among which we mention [14]:

1. The purpose of their organization: the promotion of Romanian music of the area the traditional music festival the Trio Transilvan retrieves and preserves a specific repertoire of the area, for the string trio; the Cluj Modern contemporary music festival is an event that promotes contemporary cultivated music, capitalizing on the artistic potential of Cluj Napoca (performers, composers, musicologists), proposing a showcase of the Cluj school of composition and representing a high professional challenge. It is a niche festival, which features confer it an aura of uniqueness in the national cultural landscape [15];

2. A constant audience interested in the thematic content and of high professional level [16] the Trio Transilvan festival also includes a contest of the trio ensembles participating in the festival. This type of competition has always existed, even if not in an institutionalized form, when the village musicians competed to prove their qualities and make a name for themselves [17]. The Cluj Modern festival represents an advance of contemporary musical creation, with many searches, innovations, experiments or syntheses signed by contemporary creators;

3 . The main objective of the organizing public institutions is the education and the support of some cultural activities: the City Hall, the Local Council in Gherla and the Cluj County Centre for Preservation and Promotion of Traditional Culture for the Trio Transilvan festival, and the Music Academy in Cluj, the Union of Composers and Musicologists in Romania, and Sigismund Toduţă Foundation for the Cluj Modern festival, respectively;

4. The venues of events in attractive areas [18]. The Trio Transilvan festival is held in Gherla, a town in Cluj County that has a lot of neighbouring village communities but lacks an artistic institution employing musicians; this way the festival is known and frequented by the locals every year [5; 19]. The Cluj Modern festival is organized in a higher education institution, benefiting from professional coordination, organizational assistance and the interest of the specialists in the domain;

5. Limited financial support provided by co-organizing institutions [20], the Ministry of Culture and various sponsors.

The novelty of the study concerns the fact that in the field of cultural management the specialists did not investigate the organizational efficiency of some festivals coordinated by cultural non-profit organizations, heritage or educational organizations in which the task of adopting managerial approaches is assigned to specialists from the institutions subordinated to the state. In the case of many cultural 
institutions in Romania, these specialists belong to commissions within the Ministry of Culture and Religious Affairs, or they are members of the County Councils or of the Local Councils. Public events do not seek profit and have different social missions.

\section{Methodology}

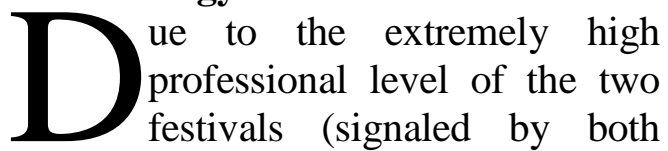
specialists and the attendees) in order to ensure the continuity of these events, it is useful to have a set of information from the perspective of the actors involved, regarding the risks that may arise in their organization and unfolding. The results may subsequently be used both for risk assessment and for the development of appropriate proactive policies, with the aim of minimizing their effects.

In order to assess the likelihood of a risk, starting from the frequency of materialization of risks from the previous editions of the mentioned events, a questionnaire divided into 5 sections was applied to 60 people directly involved in the development of the two events: directors of coorganizing institutions, festival directors, financial managers, administrative staff, artists, volunteers. The study has a quantitative component, which employed a survey conducted on two samples of 30 respondents. The questionnaires applied to the participants in the two cultural events, the Cluj Modern and the Trio Transilvan, were identical, in order to capture the specificities of each organizational structure and were structured on the following dimensions: the hierarchy of the types of risk, the actions that may affect the unfolding of the event, the relationship between the type of risk and the unfolding of the event, the main steps that can be taken to mitigate the effects of potential risks, the identification of the elements of impact regarding the identified risk. The present study investigates activities that can determine risk situations in the case of the two festivals, representing the second level of statistical approach (which in this paper was indicated by letter B) in the hierarchy of the studied criteria. The data were collected at the end of the two festivals, in the autumn of 2018 (Trio Transilvan) and the spring of 2019 (Cluj
Modern), so that the respondents were able to evaluate in a valid manner recent held editions. Different probability scales, measured on either three (low, moderate, high) or five levels (very, fairly, a little, very probable or with an average probability) were used as the assessment tool, the probability boundaries indicating the perception of the interviewees and on the uncertainty of the mentioned risks. The statistical survey was carried out through the SPPS program [21], the identification of risk sources being considered decisive in the proper evaluation of the risks faced by the organizing institutions.

\section{Results}

7 o the question How likely are the following actions able to influence the unfolding of the event? there were delineated activities that in the years prior to 2019 were considered by the organizers as generating risk situations. These were related to the following circumstances.

Firstly, poor quality of implementation of the event (B1); it is known that the requirement for successful implementation of a festival led to the creation of numerous researches, implementation models and successful recipes have been identified, extreme cases have been examined to help avoid failures [19]. In the case of the two festivals, the respondents appreciated the level of implementation of the events as shown in Figure 1.

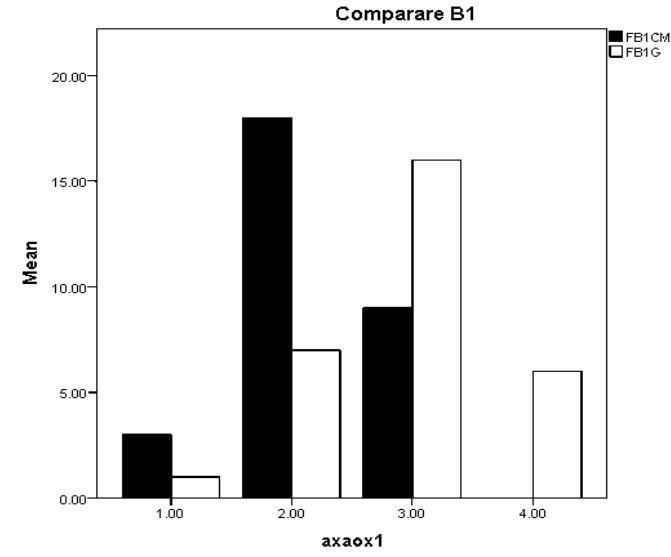

Fig. 1. Graphical comparison of evaluation related to poor implementation quality for the two festivals

For a clear conclusion, we compare the respondent response averages (Table 1). 
Table 1

Descriptive statistics

\begin{tabular}{|l|c|c|c|c|c|}
\hline \multicolumn{1}{|c|}{ Festival } & N & Minimum & Maximum & Mean & Std. deviation \\
\hline Trio Transilvan (B1) & 30 & 1.00 & 4.00 & 2.9000 & 0.75886 \\
\hline Cluj Modern (B1) & 30 & 1.00 & 3.00 & 2.2000 & 0.61026 \\
\hline
\end{tabular}

According to the following tables, in the case of the Trio Transilvan festival, the poor quality of the event implementation may negatively influence the event's unfolding to a lesser extent than the organizers of Cluj Modern consider (mean 2.9 is greater than 2.2 , since 2.9 is closer to 3 equal to "medium probability" than 2.2 which is closer to 2 and equal to " $60-80 \%$ probability").

Secondly, the size of the event is wider than the expected number of attendees (B2) [22] (Fig. 2). The estimation of the number of participants was a conditional probability and was evaluated by the organizers of the two festivals as follows: regarding the Trio Transilvan festival, it is considered that the size of the event may negatively influence the performance to a lesser extent than do the organizers of the Cluj Modern festival (mean 3.3667 is greater than 2.6 according to Table 2).

In order to establish a certainty of the mentioned risks, a correlation between two items belonging to different groups of questions from the applied questionnaire was made: Poor quality of event implementation / Size of the event is greater than Number of expected attendees, concluding that in the case of the Cluj Modern festival there is a correlation, coefficient is 69\% (Table 3 and 4).

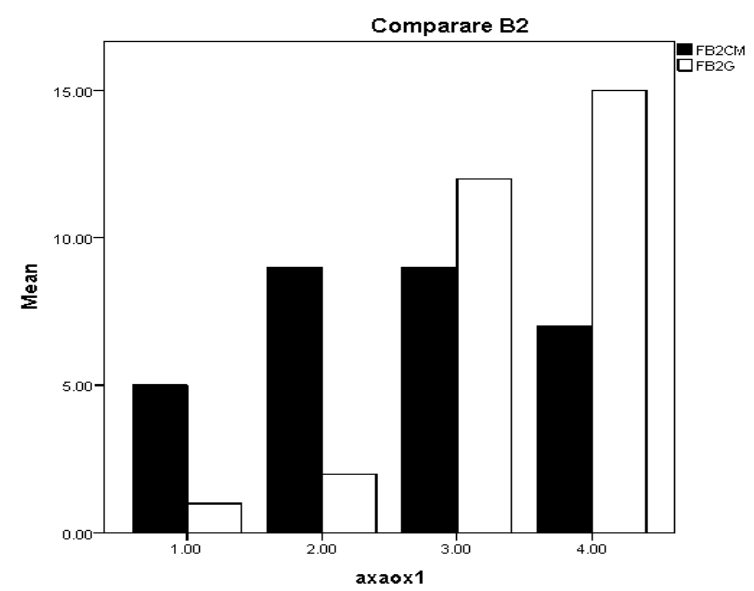

Fig. 2. Graphical comparison event size and number of attendees in the two festivals

Descriptive statistics

\begin{tabular}{|l|c|c|c|c|c|}
\hline \multicolumn{1}{|c|}{ Festival } & $\mathbf{N}$ & Minimum & Maximum & Mean & Std. deviation \\
\hline Trio Transilvan (B2) & 30 & 1.00 & 4.00 & 3.3667 & 0.76489 \\
\hline Cluj Modern (B2) & 30 & 1.00 & 4.00 & 2.6000 & 1.03724 \\
\hline
\end{tabular}

Table 3

Correlation matrix

\begin{tabular}{|l|l|l|c|c|}
\hline \multicolumn{2}{|c|}{} & Cluj Modern (B1) & Cluj Modern (B2) \\
\hline \multirow{4}{*}{ Spearman's rho } & \multirow{3}{*}{$\begin{array}{l}\text { Cluj } \\
\text { Modern (B1) }\end{array}$} & Correlation coefficient & 1.000 & $0.693^{*}$ \\
\cline { 2 - 5 } & & Sig. (2-tailed) & 0.0 & 0.000 \\
\cline { 2 - 5 } & \multirow{2}{*}{$\begin{array}{l}\text { Cluj } \\
\text { Modern (B2) }\end{array}$} & Correlation coefficient & 30 & 30 \\
\cline { 3 - 5 } & & Sig. (2-tailed) & $0.693^{*}$ & 1.000 \\
\cline { 3 - 5 } & $\mathbf{N}$ & 30 & 0.0 \\
\hline
\end{tabular}

Note: * Correlation is significant at the 0.01 level (2-tailed).

Table 4

Characteristics of model coefficients

\begin{tabular}{|l|c|c|c|c|c|}
\hline \multirow{2}{*}{ Model } & \multicolumn{2}{|c|}{ Unstandardized coefficients } & Standardized coefficients & \multirow{2}{*}{ t } & \multirow{2}{*}{ Sig. } \\
\cline { 2 - 5 } & B & Std. error & Beta & 5.095 & 0.000 \\
\hline Constant & 1.167 & 0.229 & - & 4.848 & 0.000 \\
\hline Cluj Modern (B2) & 0.397 & 0.082 & 0.676 & 0.676 \\
\hline
\end{tabular}

Note: Dependent Variable is the Cluj Modern (B1). 
Here the variables evolve in the same direction, that is, small values that mean a "high probability of risk", so if the number of expected attendees decreases, the quality of the event diminishes. The results are statistically significant, therefore the null hypothesis $\mathrm{H} 0$ : "the test has no statistical significance" is rejected.

Thirdly, the number of attendees is low, below expectations (B3) [15] (Fig. 3). Estimating the number of participants at a festival is a frequently used assessment tool [23], based on which various marketing and management parameters are established. A comparison made on this indicator shows that in the case of the Trio Transilvan it is considered that the reduced number of attendees can negatively influence the performance of the event only to a small extent, less than considered by the organizers of the Cluj Modern festival (mean 3.3333 is greater than 2.6667, Table 5).
Realizing a correlation between the number of attendees and the promotion of the event (an item from a different section of the questionnaire) a correlation of $\mathrm{R}$ equal to $47.8 \%$ was found in the case of the Cluj Modern Festival (Table 6 and 7).

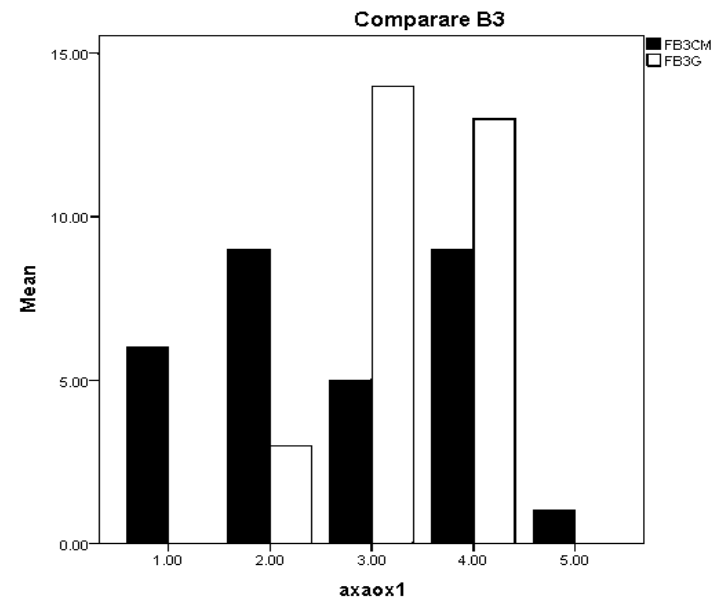

Fig. 3. Graphical comparison of the risk related to the number of attendees in the two festivals

Table 5

Descriptive statistics

\begin{tabular}{|l|c|c|c|c|c|}
\hline \multicolumn{1}{|c|}{ Festival } & N & Minimum & Maximum & Mean & Std. deviation \\
\hline Trio Transilvan (B3) & 30 & 2.00 & 4.00 & 3.3333 & 0.66089 \\
\hline Cluj Modern (B3) & 30 & 1.00 & 5.00 & 2.6667 & 1.21296 \\
\hline
\end{tabular}

Table 6

Correlation matrix

\begin{tabular}{|l|c|c|c|}
\hline \multicolumn{2}{|c|}{} & Cluj Modern (B3) & Cluj Modern (B2) \\
\hline \multirow{3}{*}{$\begin{array}{l}\text { Moduj } \\
\text { Morn (B3) }\end{array}$} & Pearson correlation & 1 & $0.478^{*}$ \\
\cline { 2 - 4 } $\begin{array}{l}\text { Cluj } \\
\text { Modern (B2) }\end{array}$ & $\mathbf{N}$ & - & 30.008 \\
\cline { 2 - 4 } & Pearson correlation & $0.478^{*}$ & 1 \\
\cline { 2 - 4 } & Sig. (2-tailed) & 0.008 & - \\
\cline { 2 - 4 } & $\mathbf{N}$ & 30 & 30 \\
\hline
\end{tabular}

Note: * Correlation is significant at the 0.01 level (2-tailed).

Table 7

Characteristics of model coefficients

\begin{tabular}{|l|c|c|c|c|c|}
\hline \multirow{2}{*}{ Model } & \multicolumn{2}{|c|}{ Unstandardized coefficients } & Standardized coefficients & \multirow{2}{*}{ t } & \multirow{2}{*}{ Sig. } \\
\cline { 2 - 6 } & B & Std. error & Beta & 3.338 & 0.002 \\
\hline Constant & 1.503 & 0.450 & - & 2.876 & 0.008 \\
\hline Cluj Modern (B2) & 0.634 & 0.1 & 0.478 & \\
\hline
\end{tabular}

Note: Dependent variable is Cluj Modern (B3).

The need to promote the event (amplified with a subunit coefficient, therefore reduced to the "greatly reduced risk" category) generates an increase in the value for the risk of a small number of attendees, i. e. the translation of this variable to the upper category of "unlikely risk." The results are statistically significant, therefore the null hypothesis H0: "the test has no statistical significance" is rejected. It should be noted that there is no correlation of this type regarding the Trio Transilvan festival. 
Another correlation that resulted in statistically significant data, a correlation of $\mathrm{R}$ is equal to $41 \%$, was achieved between the
Poor quality of event implementation / Low number of attendees (Table 8 and 9).

Table 8

Correlation matrix

\begin{tabular}{|c|c|c|c|c|}
\hline & & & Cluj Modern (B1) & Cluj Modern (B3) \\
\hline \multirow{6}{*}{ Spearman's rho } & \multirow{3}{*}{$\begin{array}{l}\text { Cluj } \\
\text { Modern (B1) }\end{array}$} & Correlation coefficient & 1.000 & $0.410^{*}$ \\
\hline & & Sig. (2-tailed) & 0.0 & 0.025 \\
\hline & & $\mathbf{N}$ & 30 & 30 \\
\hline & \multirow{3}{*}{$\begin{array}{l}\text { Cluj } \\
\text { Modern (B3) }\end{array}$} & Correlation coefficient & $0.410^{*}$ & 1.000 \\
\hline & & Sig. (2-tailed) & 0.025 & 0.0 \\
\hline & & $\mathbf{N}$ & 30 & 30 \\
\hline
\end{tabular}

Note:* Correlation is significant at the 0.05 level (2-tailed).

Table 9

Characteristics of model coefficients

\begin{tabular}{|l|c|c|c|c|c|}
\hline \multirow{2}{*}{ Model } & \multicolumn{2}{|c|}{ Unstandardized coefficients } & Standardized coefficients & \multirow{2}{*}{ t } & \multirow{2}{*}{ Sig. } \\
\cline { 2 - 6 } & B & Std. error & Beta & 6.494 & 0.000 \\
\hline Constant & 1.638 & 0.252 & - & 2.444 & 0.021 \\
\hline Cluj Modern (B3) & 0.211 & 0.086 & 0.419 & 2 & 2.0219 \\
\hline
\end{tabular}

Note: Dependent variable is Cluj Modern (B1).

It must be noted that if the role of the variables is reversed, i. e. the Number of attendees is reduced due to the implementation of the event; the results are not statistically significant.

Fourth, there are technical issues (sound amplification, image design, etc.) (B4). In organizing an event involving the production and unfolding of sounds, the preoccupations for achieving concert venues with good acoustics represent a priority [12]. The risk of technical problems is considered possible in most cases (Fig. 4). The situation of the two festivals highlights the fact that the technical problems may affect negatively the unfolding of the event, to a lesser extent in the case of the Trio Transilvan festival (mean 2.7 is greater than 2.5), the differences between the two festivals are not significant (Table 10).
A correlation was made between two items of the survey: Poor quality of implementation of the event / Technical problems, resulting in a small correlation, where $\mathrm{R}$ is equal to $36.2 \%$ (Table 11 ).

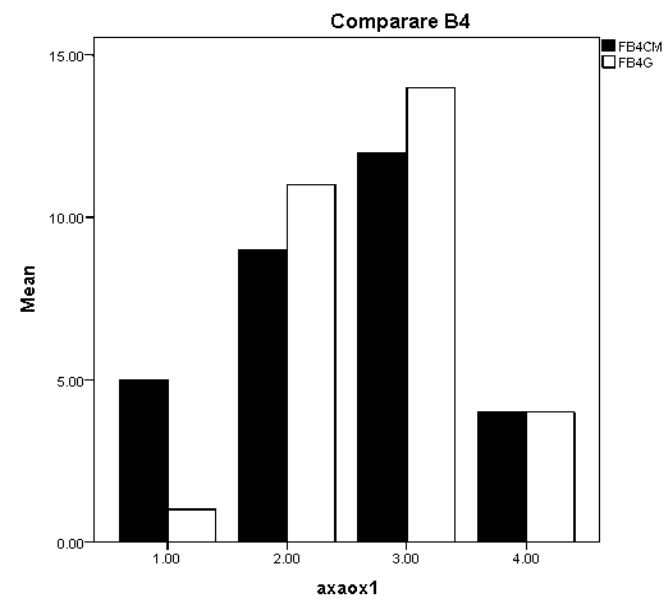

Fig. 4. Graphical comparison on the risk of technical problems in the two festivals

Descriptive statistics

\begin{tabular}{|l|c|c|c|c|c|}
\hline \multicolumn{1}{|c|}{ Festival } & N & Minimum & Maximum & Mean & Std. deviation \\
\hline Trio Transilvan (B4) & 30 & 1.00 & 4.00 & 2.7000 & 0.74971 \\
\hline Cluj Modern (B4) & 30 & 1.00 & 4.00 & 2.5000 & 0.93772 \\
\hline
\end{tabular}


Correlation matrix

\begin{tabular}{|l|l|c|c|}
\hline \multicolumn{2}{|c|}{} & Cluj Modern (B1) & Cluj Modern (B4) \\
\hline \multirow{3}{*}{$\begin{array}{l}\text { Cluj } \\
\text { Modern (B1) }\end{array}$} & Pearson Correlation & 1 & $0.362^{*}$ \\
\cline { 2 - 4 } & Sig. (2-tailed) & - & 0.050 \\
\cline { 2 - 4 } & N & 30 & 30 \\
\hline \multirow{3}{*}{$\begin{array}{l}\text { Modern (B4) } \\
\text { Mearson Correlation }\end{array}$} & Sig. (2-tailed) & $0.362^{*}$ & 1 \\
\cline { 2 - 4 } & N & 0.050 & 30 \\
\hline
\end{tabular}

Note: * Correlation is significant at the 0.05 level (2-tailed).

Fifth, the human resource (employees / volunteers, B5) is insufficient (Fig. 5). The role and importance of the correct dimensioning of the human resource in organizing a festival has led to the creation of action strategies involving a considerable number of people. This parameter is an important part of event management, with managers playing an active role in managing their own staff. According to Table 12, the organizers of the Trio Transilvan festival consider that insufficient human resources are affecting with less probability the unfolding of the event if considered by the Cluj Modern.

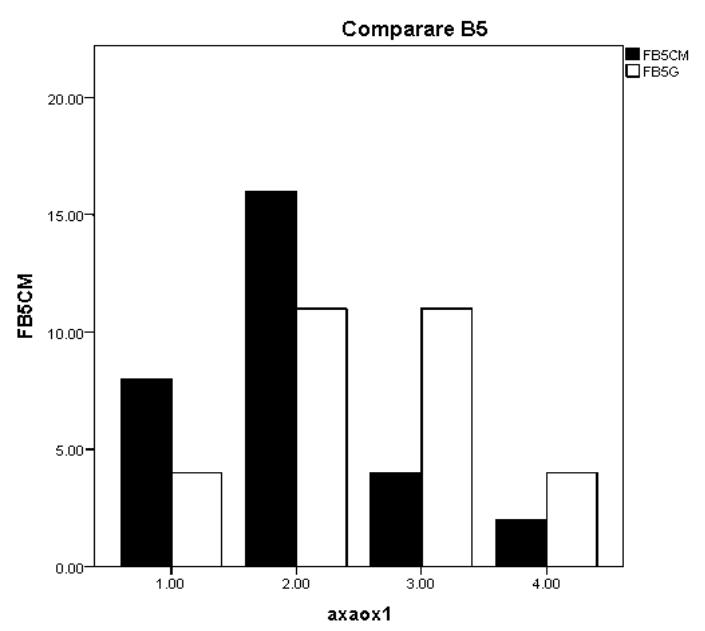

Fig. 5. Comparison of the risk related to the insufficiency of human resources for the two festivals

Table 12

Descriptive statistics

\begin{tabular}{|l|c|c|c|c|c|}
\hline \multicolumn{1}{|c|}{ Festival } & $\mathbf{N}$ & Minimum & Maximum & Mean & Std. deviation \\
\hline Trio Transilvan (B5) & 30 & 1.00 & 4.00 & 2.5000 & 0.90019 \\
\hline Cluj Modern (B5) & 30 & 1.00 & 4.00 & 2.0000 & 0.83045 \\
\hline
\end{tabular}

And in conclusion, inadequacy of funds / costs is a risk frequently encountered in the cultural sector (B6), especially when fund-raising structures are not involved in organizing events (Fig. 6). The economic variable relates the sources of financing (e. g. public funding or community co-financing) to the sum of all the expenditure planned for the event [20]. In the case of the two events, there is a common opinion about the importance of financing, the Trio Transilvan considers that insufficient funds can negatively influence the unfolding of the event. For comparison, the means is 2.7333 that is greater than 2.2667 (Table 13).

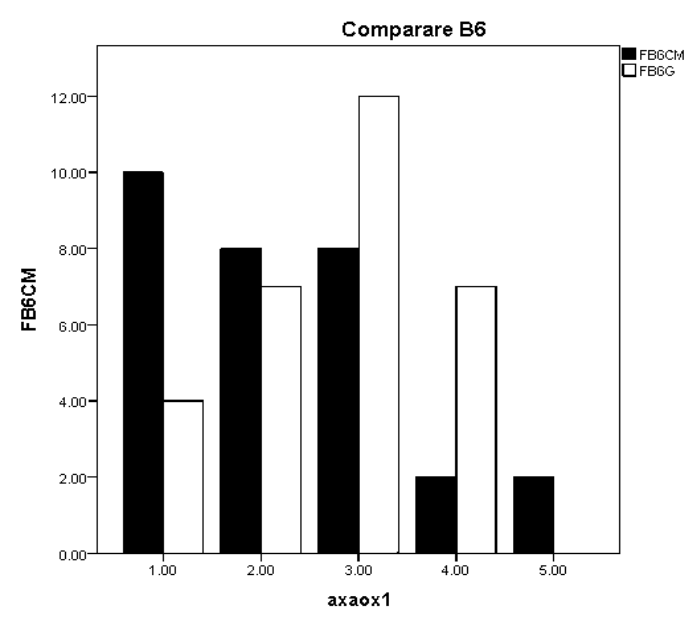

Fig. 6. Graphical comparison between the risk of inadequacy of funds for the two festivals 
Descriptive statistics

\begin{tabular}{|l|c|c|c|c|c|}
\hline \multicolumn{1}{|c|}{ Festival } & N & Minimum & Maximum & Mean & Std. deviation \\
\hline Trio Transilvan (B6) & 30 & 1.00 & 4.00 & 2.7333 & 0.98027 \\
\hline Cluj Modern (B6) & 30 & 1.00 & 5.00 & 2.2667 & 1.20153 \\
\hline
\end{tabular}

The analysis indicates the significance of the risk problem in organizing the festivals.

\section{Discussion}

significant part of the
literature on the festivals
highlighted the major risks to which the events involving a massive participation of people are exposed to, starting from the safety and organizational legality. A frequently mentioned risk is the cancellation of the presence of key actors at the event, which may compromise the event itself. Designing various activities, sometimes simultaneous with the specific ones, represents a way to reduce this type of risk, even if these actions involve additional costs. For instance, the organizers of the Trio Transilvan festival adjoined the basic concerts with an interpretive contest (instrumental trio), which increased the interest of the audience as well as the musicians in the area, and corresponded to the main objective of the event: to promote and preserve the traditional musical repertoire.

Another aspect we noticed is related to the management of the technical personnel involved at the time of the event: volunteers, workers, sound engineers. Most of them carry out unpaid activities, the quality of their actions being controllable only to a limited extent. In the case of the Cluj Modern festival, the volunteers from the festival were selected from the students of the organizing institution and the technical issues were solved with the human resources employed in the same institution, which is why there were no reported risks in this direction.

One more aspect considered in the literature refers to the need to explore the risk in relation to the specificity of the national organizational culture, highlighting the fact that a strategy for preventing and minimizing the risk of an event is managed differently in the various national cultures [24].
In the case of the Romanian state cultural organizations, they have a social and educational mission with actions to create artistic products, being financially supported through public funds. Artistic production is usually delegated to a professional (conductor, director, dance teacher), who assumes artistic responsibility only from the moment he was appointed. The functioning of the organization is transferred to an external party, functions such as marketing, human resources, accounting have only a supporting role, as they serve artistic decisions. The level of risk is significant because an artistic representation is in fact an intangible product, with an unpredictable evolution and an unpredictable level of risk. These characteristics, however, do not represent features of all cultural organizations, which in turn may belong to different sectors: arts, cultural industries and the media, but one of the defining characteristics of the artistic sector is that the artistic vision comes before market considerations, therefore public interest takes precedence over the taste of the audience.

Identifying risks, analyzing them, planning preventive measures as well as controlling them can be facilitated by employing verified risk management techniques and implementing effective risk management strategies associated with designing, planning and producing public events [25].

\section{Conclusions \\ Oollowing the quantitative analysis 1 of the assessment of the 1 organizational risk of two artistic} events by non-profit cultural organizations, it was noticed that the organizers of the Trio Transilvan festival are more detached about the various negative influences that could affect the development of the event. Analysing the average values of this festival, the highest risk for an inappropriate development of the event is represented by the insufficient human 
resource, and the lowest risk is related to the size of the event, that is higher than the expected number of attendees.

For the Cluj Modern festival the averages on the five categories analysed statistically are approximately equal, being placed around a medium risk probability (in other words much more uniform than the other analysed festival), with the mention that here as well the risk of the human resource shortage is considered the highest, while the lowest risk is linked to the poor implementation of the event. It can be concluded that the organizers of the Cluj Modern festival have a better control in risk management.

For the management of festivals that mainly have a social and educational mission, it is therefore required to avoid riskgenerating factors such as:

- inviting performers who are to a lesser extent familiar with the show industry (such as the participants in the Trio Transilvan festival), the presence of professional artists significantly reducing the risk of the artistic development of the event;

- investments are required in the human resource participating in the organization of an event, as they play an important role in the efficiency of the use of material, financial, informational resources;

- professionalizing the field of cultural management by employing specialists in fundraising as well as marketing, to avoid risks related to financing the event but also to the insufficient promotion of events.

However, it is recommended to apply a proactive management style, focused on designing and implementing measures based on the identification of possible risks before they materialize and cause devastating consequences for the unfolding of events.

In the future, the inclusion of the risk analysis in the cultural management practices could determine the limitation of their effects both financially and in the functionality and quality of the events.

\section{References}

1. Axelsen M., Swan T. Designing festival experiences to influence visitor perceptions: The case of a wine and food festival. Journal of Travel Research, 2010, vol.49, no. 4, pp.436-450. doi: $10.1177 / 0047287509346796$.

2. Jaeger K., Mykletun J.R. Festivals, identities, and belonging. Event Management, 2013, vol. 17, pp. 213-226.

3. Ferdinand N., Williams N.L. International festivals as experience production systems. Tourism Management, 2013, vol. 34, pp. 202-210.

4. Hiller R.S. The importance of quality: How music festivals achieved commercial success. Journal of Cultural Economics, 2015, vol. 40, iss. 3, pp. 309-334. doi: 10.1007/s10824-015-9249-2.

5. Laing J., Mair J. Music festivals and social inclusion - The festival organizers' perspective. Leisure Sciences: An Interdisciplinary Journal, 2015, vol. 37 (3), pp. 252-268.

6. Nistor R.L, Nedelcut A.C. Evaluating the promotion of two music events. Bulletin of the Transilvania University of Braşov, Series VIII: Performing Arts, 2017, iss. 2, pp. 73-84.

7. Wilson J., Arshed N., Shaw E. Expanding the domain of festival research: A review and research agenda. International Journal of Management Reviews, 2017, vol. 19 (2), pp. 195-213.

8. Grunwell S., Ha I.S. Film festivals: An empirical study of factors for success. Event Management, 2007, vol. 11, pp. 201-210.

9. Getz D., Andersson T.D., Carlsen J. Festival management studies. International Journal of Event and Festival Management, 2010, vol. 1, no. 1, pp. 29-59.

10. Van Winkle C.M., Woosnam K.M. Sense of community and perceptions of festival social impacts. International Journal of Event and Festival Management, 2014, vol. 5, no. 1, pp. 22-38.

11. Ciocoiu N. Managementul riscului. Teorii, practici, metodologii. Editura ASE, Bucuresti, 2008. $206 \mathrm{p}$.

12. Mervi L., Tanja J. Reasons for networking in institutionalized music productions: Case studies of an opera house and a music festival. International Journal of Arts Management. 2016, vol. 18, no. 3, pp. 50-66. 
13. Ribeiro de Almeida C. Key concepts in event management. International Journal of Contemporary Hospitality Management. 2014, vol. 26, no. 2, pp. 326-327.

14. Nedelcut A.C, Nistor R.L. Assessing the impact of managerial actions in the case of a Traditional Romanian Music Festivals. 5th International Multidisciplinary Scientific Conference on Social Sciences and Arts SGEM 2018, Vienna ART Conference Proceedings, 19-21 March, 2018, Vol. 5, iss. 6.1, pp. 11-18. doi: 10.5593/sgemsocial2018H/61/S07.002.

15. Nedelcut N. The Cluj Modern contemporary music festival analyzed by its organizer. Studia Universitatis Babes-Bolyai - Musica, 2017, iss. 2, pp. 7-15.

16. Iqbal M.Z., Akbar S., Budhwar P. Effectiveness of performance appraisal: An integrated framework. International Journal of Management Reviews, 2015, vol. 17, pp.510-533. doi: 10.1111/ijmr.12050.

17. Reid S. Event stakeholder management: Developing sustainable rural event practices. International Journal of Event and Festival Management, 2011, vol. 2, no. 1, pp. 20-36.

18. Vestrum I. The embedding process of community ventures: Creating a music festival in a rural community. Entrepreneurship and Regional Development, 2014, vol. 26, iss. 7-8, pp. 619-644.

19. Frost W., Laing, J. Avoiding burnout: The succession planning, governance and resourcing of rural tourism festivals. Journal of Sustainable Tourism, 2015, vol. 23, iss. 8-9, pp. 1-20.

20. Lucia D.M. Economic performance measurement systems for event planning and investment decision making. Tourism Management, 2013, vol. 34, pp. 91-100.

21. Flamholtz E.G., Randle Y. Corporate Culture: The ultimate strategic asset. Stanford University Press, 2011.264 p.

22. Van Aalst I., van Melik R. City festivals and urban development: Does place matter? European Urban and Regional Studies, 2012, vol. 19 (2), pp. 195-206.

23. Song Z., Xing L., Chathoth P.K. The effects of festival impacts on support intentions based on residents' ratings of festival performance and satisfaction: A new integrative approach. Journal of Sustainable Tourism, 2014, vol. 23, no. 2, pp. 316-337.

24. Liu J., Meng F., Fellows R. An exploratory study of understanding project risk management from the perspective of national culture. International Journal of Project Management, 2015, vol. 33, iss. 3 , pp. $564-575$.

25. Rutherford Silvers J. Risk management for meetings and events. London, Routledge, 2008. $384 \mathrm{p}$.

Received May 16, 2019; accepted September 11, 2019

\section{Information about the Authors}

Nistor Razvan Liviu - PhD in Reliability, Director of Department of Management, Faculty of Economics and Business Administration, Babes-Bolyai University (58-60, Teodor Mihali st., Cluj-Napoca, 400591, Romania; e-mail: rasvan.nistor@econ.ubbcluj).

Nedelcut Amalia Cristina - PhD Researcher, Faculty of Economics and Business Administration, Babes-Bolyai University (58-60, Teodor Mihali st., Cluj-Napoca, 400591, Romania; e-mail: amalia.nedelcut@econ.ubbcluj).

\section{Список литературы}

1. Axelsen M., Swan T. Designing festival experiences to influence visitor perceptions: The case of a wine and food festival // Journal of Travel Research. 2010. Vol. 49, № 4. P. 436-450. doi: 10.1177/0047287509346796.

2. Jaeger K., Mykletun J.R. Festivals, identities, and belonging // Event Management. 2013. Vol. 17. P. 213-226.

3. Ferdinand N., Williams N.L. International festivals as experience production systems // Tourism Management. 2013. Vol. 34. P. 202-210.

4. Hiller R.S. The importance of quality: How music festivals achieved commercial success // Journal of Cultural Economics. 2015. Vol. 40, Iss. 3. P. 309-334. doi: 10.1007/s10824-015-9249-2. 
5. Laing J., Mair J. Music festivals and social inclusion - The festival organizers' perspective // Leisure Sciences: An Interdisciplinary Journal. 2015. Vol. 37 (3). P. 252-268.

6. Nistor R.L, Nedelcut A.C. Evaluating the promotion of two music events // Bulletin of the Transilvania University of Braşov, Series VIII: Performing Arts. 2017, Iss. 2. P. 73-84.

7. Wilson J., Arshed N., Shaw E. Expanding the domain of festival research: A review and research agenda // International Journal of Management Reviews. 2017. Vol. 19 (2). P. 195-213.

8. Grunwell S., Ha I.S. Film festivals: An empirical study of factors for success // Event Management. 2007. Vol. 11. P. 201-210.

9. Getz D., Andersson T.D., Carlsen J. Festival management studies // International Journal of Event and Festival Management. 2010. Vol. 1, № 1. P. 29-59.

10. Van Winkle C.M., Woosnam K.M. Sense of community and perceptions of festival social impacts // International Journal of Event and Festival Management. 2014. Vol. 5, № 1. P. 22-38. $206 \mathrm{p}$.

11. Сiocoiu N. Managementul riscului. Teorii, practici, metodologii. Editura ASE, Bucuresti, 2008.

12. Mervi L., Tanja J. Reasons for networking in institutionalized music productions: Case studies of an opera house and a music festival // International Journal of Arts Management. 2016. Vol. 18, № 3. P. 50-66.

13. Ribeiro de Almeida C. Key concepts in event management // International Journal of Contemporary Hospitality Management. 2014. Vol. 26, № 2. P. 326-327.

14. Nedelcut A.C, Nistor R.L. Assessing the impact of managerial actions in the case of a Traditional Romanian Music Festivals // 5th International Multidisciplinary Scientific Conference on Social Sciences and Arts SGEM. Vienna ART Conference Proceedings, 19-21 March 2018. 2018. Vol. 5, Iss. 6.1. P. 11-18. doi: 10.5593/sgemsocial2018H/61/S07.002.

15. Nedelcut $N$. The Cluj Modern contemporary music festival analyzed by its organizer // Studia Universitatis Babes-Bolyai - Musica. 2017. Iss. 2. P. 7-15.

16. Iqbal M.Z., Akbar S., Budhwar P. Effectiveness of performance appraisal: An integrated framework // International Journal of Management Reviews. 2015. Vol. 17. P. 510-533. doi: 10.1111/ijmr.12050.

17. ReidS. Event stakeholder management: Developing sustainable rural event practices // International Journal of Event and Festival Management. 2011. Vol. 2, № 1. P. 20-36.

18. Vestrum I. The embedding process of community ventures: Creating a music festival in a rural community // Entrepreneurship and Regional Development, 2014. Vol. 26, Iss. 7-8. P. 619-644.

19. Frost W., Laing, J. Avoiding burnout: The succession planning, governance and resourcing of rural tourism festivals // Journal of Sustainable Tourism. 2015. Vol. 23, Iss. 8-9. P. 1-20.

20. Lucia D.M. Economic performance measurement systems for event planning and investment decision making // Tourism Management. 2013. Vol. 34. P. 91-100.

21. Flamholtz E.G., Randle Y. Corporate Culture: The ultimate strategic asset. Stanford University Press, 2011. 264 p.

22. Van Aalst I., van Melik R. City festivals and urban development: Does place matter? // European Urban and Regional Studies. 2012, Vol. 19 (2). P. 195-206.

23. Song Z., Xing L., Chathoth P.K. The effects of festival impacts on support intentions based on residents' ratings of festival performance and satisfaction: A new integrative approach // Journal of Sustainable Tourism. 2014. Vol. 23, № 2. P. 316-337.

24. Liu J., Meng F., Fellows R. An exploratory study of understanding project risk management from the perspective of national culture // International Journal of Project Management. 2015. Vol. 33. Iss. 3. P. 564-575.

25. Rutherford Silvers J. Risk management for meetings and events. London, Routledge, 2008. $384 \mathrm{p}$. 


\section{Сведения об авторах}

Нистор Разван Ливиу - PhD in Reliability, директор департамента «Менеджмент», факультет экономики и делового администрирования, Университет Бабеш-Бойяи (Румыния, 400591, г. КлужНапока, ул. Теодора Михали, 58-60; e-mail: rasvan.nistor@econ.ubbcluj).

Неделькус Амалия Кристина - аспирант, факультет экономики и делового администрирования, Университет Бабеш-Бойяи (Румыния, 400591, г. Клуж-Напока, ул. Теодора Михали, 58-60; e-mail: amalia.nedelcut@econ.ubbcluj).

\footnotetext{
Просьба ссылаться на эту статью в русскоязычных источниках следующим образом:

Nistor R.L., Nedelcut A.C. Identifying and managing risk in organizing cultural events (In the case study of the Romanian music festivals) // Вестник Пермского университета. Сер. «Экономика» = Perm University Herald. Economy. 2019. Том 14. № 3. C. 482-494. doi: 10.17072/1994-9960-2019-3-482-494
}

Please cite this article in English as:

Nistor R.L., Nedelcut A.C. Identifying and managing risk in organizing cultural events (In the case study of the Romanian music festivals). Vestnik Permskogo universiteta. Seria Ekonomika = Perm University Herald. Economy, 2019, vol. 14, no. 3, pp. 482-494. doi: 10.17072/1994-9960-2019-3-482-494 